\title{
Akik majdnem megnyerték az Atlanti csatát - A Kriegsmarine U VII. osztályú tengeralattjárói
}

\author{
II. rész
}

\begin{abstract}
A VII/C41-ES VÁLTOZAT
A VII/C41 típusváltozat motorteljesítménye és fegyverzete az elődtípuséhoz képest nem változott, a régebbi modifikációtól a megerősített nyomásálló test és az újrakonstruált könnyebb dízelmotorok különböztetik meg. A könnyebb motor tette lehetővé a vastagabb és nehezebb nyomásállóbb hajótest acéltöbbletét, de így is a búvárnaszád tömege minimálisan csökkent. A C41-esek 200-230 méter helyett akár 250 méter mélyre is merülhettek. A nagyobb mélységbe merülés az óceáni hideg és meleg vízrétegek közti manőverezést segítette, mert a szonár hatásfokát a különböző hőmérsékletű vízrétegek kisebb nagyobb mértékben befolyásolják, valamint a kisebb mélységre beállított vízibombák kikerülésének egyik taktikája volt. Nagy mélységben megrongálódott tengeralattjáróból viszont a felszínre úszás, tehát a legénység menekítése szinte lehetetlen volt. A hajót a régebbi "C" változattal párhuzamosan gyártották, az első az U 292 már 1941-ben sólyára került. Végül összesen 91 darab készült belölük, mivel a gyártói kapacitást a kisebb acéligényű régebbi $C$ változat, később pedig az új konstrukciójú XXI-es és XXIII-as típus gyártására fordították.
\end{abstract}

A sorozat egységei: U 292-U 328, U 827-U 930, U 995, U 997-U 1010, U 1013-U 1025, U 1063-U 1065, U 1103U 1110, U 1163-U 1172, U 1271-U 1279, U 1301-U 1308.

15. ábra. IX. osztályú, óceáni bevetésre épített tengeralattjáró

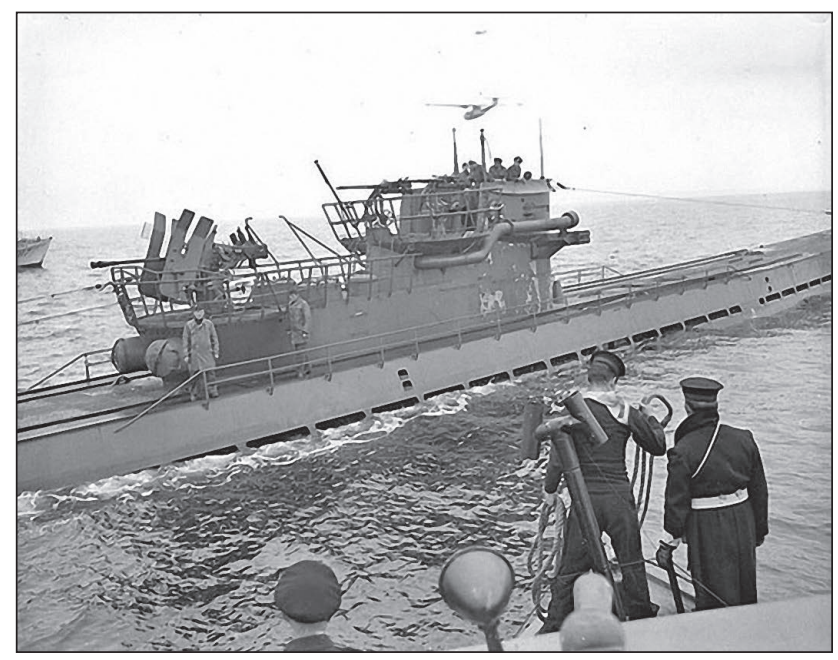

A leghíresebb VII/C41-es egység az U 995-ös, amely az egyetlen megmaradt VII. osztályú tengeralattjáró. Az építése 1942. november 25-én kezdődött a hamburgi Blohm \& Voss hajógyárban, és 1943. július 22-én készült el. A Kriegsmarine 1943. szeptember 16-án vette át a hajót. Első parancsnoka Walther Köhntopp sorhajóhadnagy volt, aki 1944. október 9-ig látta el teendőit. Köhntopp az óvatos parancsnokok közé tartozott, négy őrjáraton vett részt, 55 napot töltve a tengeren. Pályafutása során egyetlen hajót sem süllyesztett el. Valószínűleg ezért is váltották le, és helyette Hans Georg Hess sorhajóhadnagyot bízták meg a hajó irányításával. Az U 995-össel öt őrjáraton vett részt, 1944. október 14. és 1945. március 26. között. A 133 tengeren töltött nap alatt, hat hajót süllyesztett el, 9474 brt. vízkiszorítással. Ezek közül a legnagyobb hal a Liberty osztályú HORACE BUSCHNELL amerikai kereskedelmi hajó volt, amely a JW-66-os konvojban hajózott. A többi szovjet hajó volt, köztük a BO 224-es fregatt osztályú kísérőhajó, valamint kisebb méretű szovjet halászhajók és motorosok. Hess 1945. február 11-én megkapta a lovagkeresztet. A dátum jelzi, hogy a németeknél akkor már ilyen csekély eredményért is kitüntetést adományoztak. 1945-ben már alig-alig volt lehetőségük kilövésre a VII. osztályú U-bootoknak. Az U 995-öst 1945. május 9-én Tordheimban átadták a norvégoknak. A VII/C41-es naszádok eredményeit áttekintve az elavult osztállyal a parancsnokok a támadás helyett inkább a lopakodást helyezték előtérbe, sok U-boot, például az U 1277, U 1278, U 1279, U 1301, U 1303, U 1304, U 1306, U 1307 egyetlen ellenséges hajót sem torpedózott meg, amelyik egy-két hajót kilőtt, az általában az akciót követően nem tudott már elmenekülni. Az U 1302-es például 1945. március 7-én Wofgang Herwartz sorhajóhadnagy parancsnoksága alatt három hajót torpedózott meg Írország közelében, a Szent György csatornában 8386 brt. vízkiszorítással, de három kanadai fregatt, a HMCS LA HULLOISE, a HMCS SRATHADAM és a HMCS THETFORD MINES, amelyek a kísérőhajók közé tartoztak, 48 fős legénységével együtt elsüllyesztették. Néhány hajó ért el kisebb eredményeket. Az U 1023-as Heinrich Andreas Schroeteler korvettkapitány parancsnoksága alatt 1945. április 27-én megtorpedózta a 7345 tonnás RIVETON szállítóhajót Kelet-Anglia partjainál, majd május 7-én elsülylyesztette a norvég flotta NYMS 382-es aknamentesítőjét. Schroeteler 1940. óta harcolt a tengeren, és 1942. október 21-től az VII.C osztályú U 667-es parancsnoka volt. Négy őrjáratán (összesen 218 nap a tengeren), nem tudott eredmény elérni, utána kapta meg az U 1023-ast. A sikeres akció után 1945. május 2-án megkapta a lovagkeresztet.

ORCID: 0000-0001-5563-3313

** Mérnök, a Haditechnikai Intézet ny. tanácsosa, a Haditechnika folyóirat korábbi szerkesztője, ORCID: 000-0002-2008-7997 


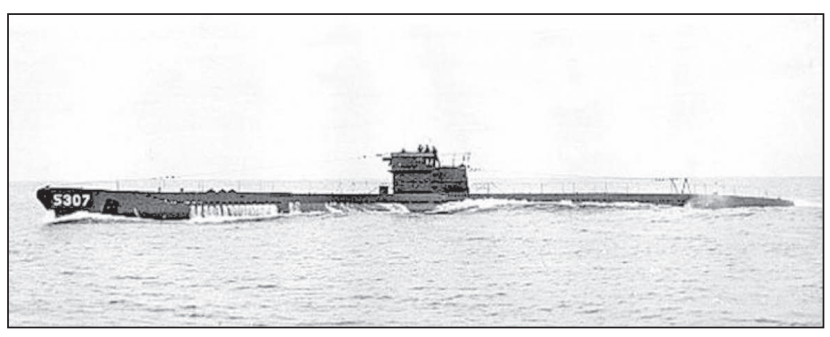

16. ábra. Az U 926-os tengeralattjárót a háború után Kya S307-es néven, a Norvég Királyi Haditengerészet is szolgálatba álította

\section{A VII/C42 VÁLTOZAT}

A VII/C42-es osztályt 1942-1943 között tervezték, hogy leváltsa a VII. osztályt. Az új változat gyakorlatilag a régi, némileg modernizált modifikációja. A nyomásálló testet komolyan megerősítették, 28 mm-es falvastagsága elméletileg 270-400 méteres mélységig biztonságos merülést tett volna lehetővé. A búvárnaszád méretei némileg növekedtek, a vastagabb fal miatt a hajó tömege 1099 tonnára emelkedett. Új, 3300 kW-os (4400 LE) teljesítményű dízelmotorokat kapott, az elektromotorok a régivel azonosak maradtak, akárcsak az akkumulátorkapacitás. A felszíni sebesség 18,6 csomóra (34 km/h-ra) növekedett, lemerülve elektromotorokkal 7,6 csomó $(14 \mathrm{~km} / \mathrm{h})$ maradt a naszád sebessége. A hatótávolság felszíni 10 csomós (19 km/h-s) gazdaságos sebességgel elérte a 23310 km-t. Az U-boot fegyverzete azonos maradt, mivel a 4 első és egy hátsó torpedóvető csőhöz már 16 torpedót szállíthatott. A fedélzeti ágyú lekerült a hajóról, mivel kísérőhajók nélküli konvoj már nem létezett, az ágyú kavitációja, pedig nagyobb zajt keltett, mint esetleges hasznot a használata. A toronyba két periszkópot szereltek, amelyeket egymástól függetlenül lehetett mozgatni. A légperiszkóp is tervezett volt. A VII/C42-es osztály gyakorlatilag sok újdonságot nem tartalmazott. A felszíni sebesség növekedését annulálta, hogy a szövetségesek kísérőhajói akár 20-30 csomós (37-55 km/h-s) sebességgel is tudtak mozogni, tehát a tengeralattjáróval csak a régi korvettek elöl tudtak volna elmenekülni a felszínen, ráadásul a lokátorral azonnal észrevették volna azokat. A szerződéseket ennek ellenére aláiratták a gyártókkal és 164 darab egység építését tervezték. Néhány naszád építése el is kezdődött, de 1943. szeptember 30-án a gyártást azonnali hatállyal leállították, hogy áttérjenek a sokkal modernebb XXI. és XXIII. osztályú tengeralattjárók gyártására. Egyetlen VIIC/42-es sem került legyártásra.

\section{A VII/D VÁLTOZAT}

A VII/D osztályt 1939 és 1940 között tervezték. A VII/C osztály meghosszabbított változata volt. Az osztály különlegessége, hogy aknarakásra tervezték, és a parancsnoki torony mögé három csoportban 5-5 db torpedóvető csövet építettek függőlegesen a hajótestbe (hasonlóan a rakétahordozó SSBN tengeralattjárókhoz). A torpedóvető csövekből 15 aknát lehetett telepíteni. A naszádok jellemzői megegyeztek a VII. osztályéval, de a $88 \mathrm{~mm}$-es többcélú löveget nem szerelték rá a hajókra. Az első egység az U 213-as volt, amelynek építését 1940. október 1 -jén Kielben kezdték meg. Az aknarakó 1941. augusztus 30-án került a Kriegsmarine szolgálatába Amelung von Varendorf fregatthadnagy parancsnoksága alatt. 1942. július 31-i pusztulásáig, egyetlen hajót sem süllyesztett el, vagy rongált meg.
A megépült egységek: U 213-U 218-ig.

A VII/D osztály egységei nem voltak annyira sikeresek, mint a flottatengeralattjárók, és elég sebezhetőek voltak. Például az U 214-es 1941. novembertől, 1944. július 26-ig vett részt a harcokban és Günther Reeder sorhajóhadnagy parancsnoksága alatt egy akció során 1942. augusztus 18-án, az SL 118 konvojból három hajót süllyesztett el. Ruppert Stock sorhajóhadnagy vezetésével további aknákat telepített, amelyeken 1943-ban két amerikai kereskedelmi hajó és egy brit halászhajó robbant fel. Gerhadt Konrad korvetthadnagy 1944. július 26-án a La Manchecsatornába vezényelte a hajót, ahol Brestnél a brit HMS COOKE fregatt elsüllyesztette, túlélő nem maradt. Az U 216-os egy évig iskolahajóként működött, majd Karl Otto Schultz sorhajóhadnagy parancsoksága alatt egyhónapos harci bevetésen vett részt, ahol egyetlen 4989 tonnás hajót süllyesztett el, majd 1942. október 20-án a Brit Királyi Légierő 334. századának Liberátor bombázója csapott le rá Irországtól délre, amelynek nyomán a teljes legénységével együtt hullámsírba merült.

Egyetlen VII/D osztályú aknarakó az U 218-as élte túl a világháborút, Ruppercht Stock sorhajóhadnagy parancsnoksága alatt. A hajó pályafutása során egy halász- és egy vitorláshajót süllyesztett el, illetve aknáin megsérült a FJORDASS nevű tanker és HMS F160 EMPIRE HALBERD partra szálló hajó. Az U 218-ast, 1945. június 2-án a skóciai Loch Ryan öbölben legénysége elsüllyesztette.

\section{A VII.F TORPEDóSZÁLLító VÁLTOZAT}

A VII.F változatot 1941-ben tervezték, elsősorban torpedók szállítására. 77,6 méter hosszukkal, és 7,3 méteres szélességükkel, a legnagyobb méretű VII. osztályú hajók voltak. Lemerülve, 1181 tonna volt a vízkiszorításuk. A torpedófegyverzetük ugyan megegyezett a korábbi VII. osztály hajóival, de ágyút nem szereltek rájuk. A búvárnaszádok $39 \mathrm{db}$ torpedót tudtak szállítani. Feladatuk nem a harc volt, hanem a többi tengeralattjáró támogatása és ellátása. A típusváltozatból négyet építettek: U 1059, U 1060, U 1061, U 1062.

Az egységek közül kettő, az U 1059-es és az U 1062-es, az úgynevezett „monszun” tengeralattjárók kiszolgáló hajójaként a közel-keleti vizekre hajózott. Monszun hajóknak a IX. C és D osztályú óceáni múveletekre tervezett hajókat nevezték, amelyek az Indiai- és a Csendes-óceánon hajtottak végre támadásokat a szövetséges hajók ellen.

17. ábra. Az U 995-ösről készített múvészi ábrázolás

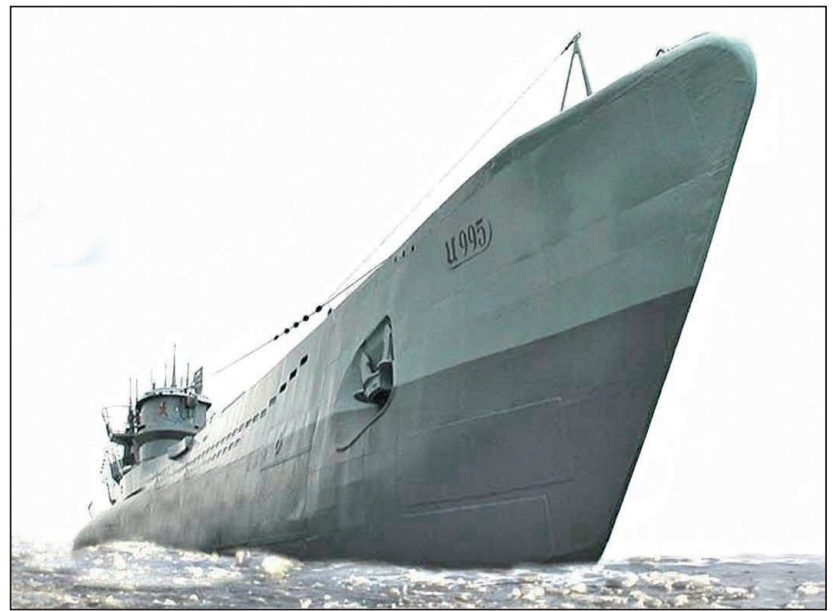




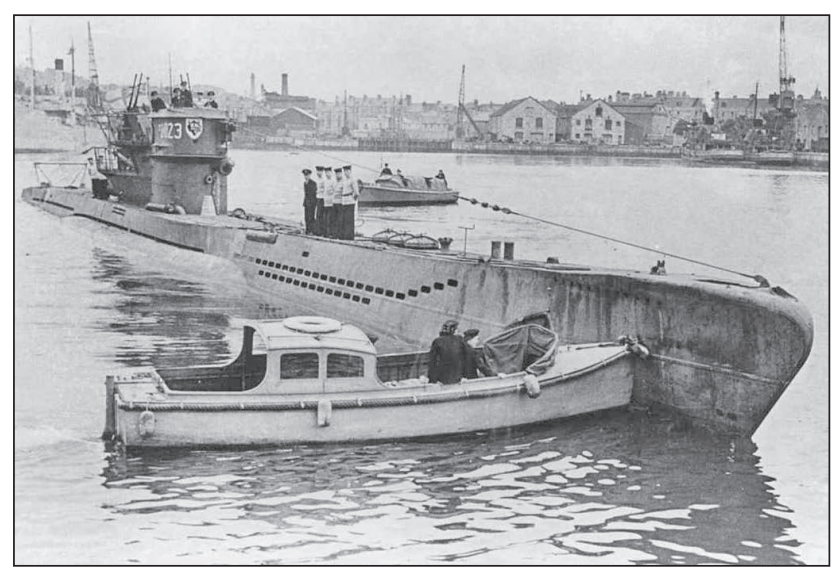

18. ábra. Az U 123-as tengeralattjáró 1945-ben, a fegyverletétel után, Plymouth kikötőjében

1942. június 4-én kezdték meg Kielben az U 1059-es építését, és 1943. május 1-én adták át a flottának. A hajó próbáit 1943. május és december között Herbert Brüninghaus sorhajóhadnagy parancsnoksága alatt végezték, majd 1944. január 1-én hajóztak ki. Március 19-én a Zöld-foki szigeteknél bukkant a tengeralattjáróra az USS BLOCK ISLAND amerikai kísérő repülőgép-hordozó légegysége, és Avenger bombázói elsüllyesztették. Legénységéből 47 fő meghalt, 8 túlélő fogságba esett. Testvérhajója az U 1062-es szintén 1943-ban készült el, és Karl Albercht sorhajóhadnagy vezetésével fél évet gyakoroltak, majd szintén 1944. január 1-én indultak el. Az U 1062-est 1944. szeptember 30-án küldte a tenger fenekére teljes legénységével együtt az USS FESSENDER romboló.

Az Atlanti-óceánra szánt U 1060-as 1943. május 15-én készült el, és Herbert Brammer sorhajóhadnagy parancsnoksága alatt kezdte meg szolgálatát. 1944. október 27-én a HMS IMPLACABLE brit repülőgép-hordozóról felszállt Firefly és Barracuda topedóvető bombázók derítették fel a svéd partok közelében felszínen úszó tengeralattjárót, majd két brit Halifax és két csehszlovák legénységú Liberátor támadta meg. A merülésképtelen hajót legénysége elhagyta, tizenketten, köztük Brammer parancsnok meghaltak, negyvenhárman élték túl a támadást.

1943. augusztusban az U 1061-es készült el, és 1945. március 19-ig Otto Hinrichs sorhajóhadnagy vezetésével két őrjáraton vett részt, valamint az 12. U-boot flottilla iskolahajójaként működött. 1945. május 9-én Skóciában, a Loch Ryan-öbölben önelsüllyesztést hajtott végre.

\section{A VII. FLAK (LÉGVÉDELMI) VÁLTOZAT}

A Brit Királyi Légierő 1942 második felétől a francia partoknál lévő tengeralattjáró-bázisok környékén és Vizcayaiöböl térségében a parti és a bombázó parancsokság repülőgépeivel folyamatosan őrjáratozott, hogy a kifutó és visszatérő búvárhajókat megtámadja. Ezt a taktikát többek között azért is fejlesztették ki, mert egyrészt korlátozott területen nagyobb lehetőség volt a tengeralattjárók felderítésére, másrészt az öblöt a németek általában nagy sebességgel felszínen hajózták át. A Short Sunderland hidroplánok, PBY Catalina repülőcsónakok és brit bombázók ellen a németek a Ju $88 \mathrm{C}$ nehézvadász változatával repülőkötelékeket vezényeltek. A tengeralattjáró-parancsnokok azonban egyre több támadást szenvedtek el, és jelentettek a BdU-nak (Befehlshaber der Unterseeboote). A tengeralattjáró-parancsnokság ezért a VII. osztályú hajókból négyet

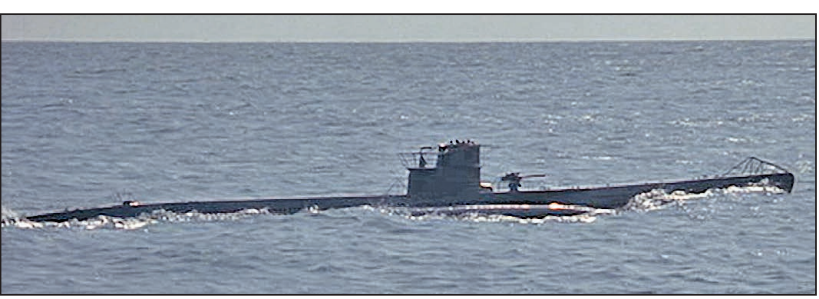

19. ábra. Képkocka a Das Boot (A hajó) címú filmböl. A filmben ténylegesen nem szerepelt VII. osztályú tengeralattjáró, csak méretarányos modellek, valamint a tengeralattjáró belső helységeit építették meg a Bavaria filmstúdióban

- az U 441-es, U 256-os, U 621-es és az U 951-es egységeket - átépítette, hogy támadó gépek ellen légvédelmi tengeralattjárónak alkalmazza. Az első ilyen egység az U 256-os volt, amely az utolsó bevetésen komolyan megrongálódott. Az U-boot-ot nem bontották szét, hanem fedélzetére nagy tűzerejű légvédelmi fegyvereket telepítettek. A 88 mm-es löveget leszerelték, és helyette kettő darab 20 mm-es négycsövű Flakvierlinget (légvédelmi gépágyút) építettek, és egy $37 \mathrm{~mm}$-es légvédelmi gépágyút is felszereltek a toronyba. A tűzerőt két egycsövű 20 mm-es gépágyú is fokozta. A torpedóvető csöveiben lévő öt torpedónak sem vittek tartalékot, kellett a hely a legénységnek, a lövegkezelőknek és a tartalék lőszereknek. A tengeralattjáró üzemanyag-kapacitását jelentősen csökkentették, és működési területét a Vizcayai-öböl térségére korlátozták. Az esetlenül kinéző búvárnaszádoknak parancsot adtak, hogy légitámadás esetén ne merüljenek le, hanem fedélzeti tűzfegyvereikkel küzdjék le a célokat. A tengeralattjáró azonban nem rendelkezett megfelelő felderítőeszközökkel, sem lőelemképzőkkel, és az imbolygó hajótest sem segítette elő a célzást. Az U 256-os első bevetésére 1943 júniusában került sor. Bár repülőgépet akkor nem lőtt le, de sikeresen űzte el a felderítő- és bombázógépeket. Ezt látva, a három további hajó átalakítását is végrehajtották. A légvédelmi naszádok novemberig tevékenykedtek, addig német források szerint kettő repülőgépet lőttek le, hat őrjárat alatt. (Az őrjáratokból hármat az U 441-es, egyet-egyet az U 256-os, U 621-es és U 953-as hajtott végre).

A német parancsnokság elrendelte, hogy hajói csoportokban keljenek át a veszélyes öblön, lehetőleg légvédelmi búvárnaszád fedezete mellett. A BdU utasítására az újabb hajók - az U 211-es, U 263-as és U 271-es - átalakítását is megkezdték, de végül visszaalakították hagyományos VII. osztályú búvárnaszádokká.

A britek válasza nagyobb légikötelékek, valamint brit tengeralattjárók, gyorsnaszádok bevetése volt, és a német U-boot veszteségek az öbölben, 1943 novemberétől kezdve ismét emelkedtek. Ezért a búvárnaszádok merülésben, légszívó periszkóp használatával, dízelmotorral keltek át a Vizcayai-öblön.

$A z \cup 256-o s$ a német flotta légvédelmi specialistája maradt. 1942. augusztus 25. és 1944. június 7 . között legénysége 7 repülőgépet lőtt le. Áldozataik között volt egy-egy Whitley illetve Halifax, két Liberátor és három Wellington bombázó. Az U 256-os a légi célokon kívül 1944. február 20-án elsüllyesztette az OM-224-es konvoj hajói közül a HMS WOODPECKER sloop-ot (nagy kísérőhajót). Az U 256-os pályafutását 1944. október 23-án fejezte be a norvégiai Bergenben, amikor légitámadás után a megrongált hajót már nem javították ki, hanem „,kannibalizálták”, az abból kiszerelt alkatrészekkel más hajókat müködtettek, majd később teljesen szétbontották.

Az U 441-es repülőgép (két Sunderland repülőcsónakot, egy Beaugfighter, egy Wellinton bombázót és egy nem 
azonosított típust) lőtt le 1943. március 20. és 1944. június 7. között. A repülőgép vadászat előtt Klaus Hartmann sorhajóhadnagy parancsnoksága alatt megtorpedózta a holland 7051 tonnás SOEKABOEMI kereskedelmi hajót. Utolsó útján, 1944. június 8-án a La Manche-csatornán a brit 224. repülőszázad Liberátora támadta meg, és teljes legénységével elsüllyesztette.

Az U 621-es nem volt sikeres a légvédelemben, két repülőgépet rongált meg, de magát a tengeralattjárót is többször megrongálták repülőgépek. A visszaalakított VII. osztályú U-boot, 1944. augusztus 18-án a francia partok közelében három kanadai romboló a HMCS OTTAWA, a HMCS KOOTENAY és a HMCS CHEUDIERE támadásának esett áldozatul, teljes legénysége odaveszett a harcban.

Az U 953-as 1942. december 17-i szolgálatba állítása után soha nem süllyesztett el hajót, légvédelmi csapdaként sem lőtt le repülőgépet. Szolgálata alatt nem sérült meg. Három parancsnoka is volt, végül Erich Steinbrink sorhajóhadnagy vezényletével, 1945. május 8-án Trodheim térségében legénysége elsüllyesztette a búvárnaszádot.

\section{IRODALOMJEGYZÉK}

Aquila. In: Bernard Edwards: Dönitz Farkasfalkái: Az Atlanti-csata 1939-1945. Bp.: LAP ICS könyvkiadó, 1998. ISBN 963 4343244;

Sárhidai Gyula: Tengerek szürke farkasai. Bp.: Maecenas könyvkiadó, 1989. ISBN 969 7425152;

Paul Herbert Freyer: Halál a tengereken. Bp.: Zrínyi Katonai Kiadó, 1979. ISBN 9633266483 ;

Lothar Günther Bucheim: A hajó. Bp.: Magvető Kiadó, 1982. ISBN 963 2718038;

Geoffrey Brooks: Hirschfeld - egy német tengeralattjáróaltiszt története, 1940-1946. Debrecen: Hajja \& Fiai Könyvkiadó, 2003. ISBN 9789639329805

Norman Franks \& Eric Zimmerman: U Bootok harca a repülőgépekkel. Debrecen: Hajja \& Fiai Könyvkiadó, 1999. ISBN 963903759 1;

Robert C. Stern: Type VII U-boats. London: Arms and Armour Press, 1997. ISBN: 9781860198557;

The U-boat Wars 1939-1945 (Kriegsmarine) and 1914-1918 (Kaiserliche Marine) and Allied Warships of WWII. http://www.uboat.net/ [2018.04.18.].

\section{Leipniker Artúr mérnök ezredes}

Leipniker Artúr mérnök ezredes hadmérnöki pályafutását a Haditechnikai Intézetben kezdte, ahol minden szakmai lépcsőt végigjárva, parancsnokként került nyugállományba. Nyugállományba vonulása után sem szakította meg kapcsolatait a szakmával és egykori kollégáival. Részt vett a szakma rendezvényein és értékes tanácsaival, észrevételeivel segítette a fiatal mérnökök munkáját.

A Csepel Motorkerékpár Gyárból 1949-ben, 2 évvel a Haditechnikai Intézet újjáalapítása után, rajzolói beosztásban került az Építési és Erődítési osztályra, amelynek akkor Gerendás István tábornok volt a vezetője. (Gerendás Istvánt később a Budapesti Müszaki Egyetemen alapított Hadmérnök Kar parancsnokává nevezték ki.)

Leipniker Artúr pályája kezdetén a legjobbaktól tanult. 1947-től az 1950es évek elejéig a HTI törzsállománya a „királyi” HTI tapasztalt hadmérnökeiből állt, akik közül visszaemlékezésében szeretettel és tisztelettel emlékezett meg dr. Feimer Lászlóról, aki részt vett a Keleti-Kárpátok erődítéseinek megtervezésében és megépítésében, Dékány Sándorról, aki optikai rendszerek tervezését végezte, Eperjesi Antalról és Nagy Artúrról, akik a lövegtervezés és -gyártás szakemberei voltak, valamint Liszka Györgyről, aki a páncélosokkal és gépjárművekkel kapcsolatos kérdések szakembere volt. A tőlük tanultak alapozták meg szakmai munkáját.

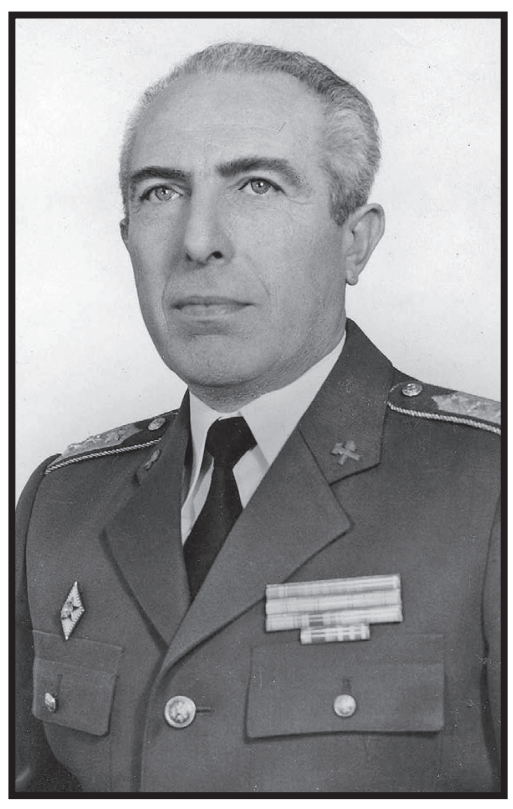

Az '50-es évek elején szovjet méretfelvételezés, vagy szovjet licenc alapján távcsövek, megfigyelőműszerek, személyi távcsövek, teodolitok gyártásvezetésével foglalkozott, majd vegyi és sugárzásvédelmi kérdések foglakoztatták. Először csak alapvető kísérleti munkát végzett, majd 1957től a Vegyivédelmi Főnökség eszközeinek kifejlesztésén dolgozott, egy új szakág előfeltételeit teremtette meg. Fejlesztői pályafutása alatt kb. 50 témát dolgozott ki és fejezett be. 1977-78-tól először a HTI parancsnokának tudományos helyettese, utána a parancsnok első helyettese, majd 1982-től először megbízott parancsnok, később - 1986-ig - kinevezett parancsnok volt.

1986-tól 1990-ig műszaki tanácsadóként dolgozott a Müszeripari Kutató Intézetben. 1990 és 1993 között pedig egy műszaki fejlesztéssel foglalkozó cég ügyvezetője volt. Pályafutása alatt egy könyvet és több mint 20 szakcikket publikált (ebből 6-ot a Haditechnikában) különböző folyóiratokban. Munkássága elismeréseként megkapta a Kiváló Feltaláló kitüntetést. Az Egyetem Szenátusa aranydiploma adományozásával ismerte el értékes mérnöki tevékenységét.

Távozásával nagy idők tanúját veszítettük el, akire hálás szívvel emlékezik az utókor.

(Dr. Hajdú Ferenc) 